\title{
The advice of the wise: afterthoughts about reality checking
}

\section{Ad Bergsma}

Published online: 28 February 2007

(C) Springer Science+Business Media B.V. 2007

\begin{abstract}
One of the aims of this special issue on happiness advice was to assess the reality value of recommendations. All papers checked empirical indications for effectiveness, typically by inspecting whether the things advised have been found to be related to happiness in empirical research. Some limitations of this approach are that some advisers used a different definition of happiness than the papers, the papers checked the advice for present day readers, not for the contemporaries of advisers, the data that is used to check the advice is most often correlative in nature, and the papers ignored personality differences. Future research should focus on a wider range of happiness advisers, look at the interaction of the advice and individual readers and address the question of the usefulness of the advice experimentally.
\end{abstract}

Keywords Happiness $\cdot$ Research agenda $\cdot$ Effectiveness of advice

One of the central questions considered in this special issue is whether happiness advice enhances in happiness of people who take it to heart. In each case study we checked whether the recommendations are in line with what is known about the conditions of happiness. Does this test do justice to the wise advisers? The following limitations must be acknowledged.

\section{Same notion of happiness?}

The evidence check is based on what we know about happiness in the sense of lifesatisfaction. However, the advice considered is sometimes based on another concept of happiness or even multiple and ill-defined views on the good life. Philosophers

\footnotetext{
A. Bergsma (ه)

Faculty of Social Sciences, Erasmus University Rotterdam, P.O. Box 1738,

3000 DR Rotterdam, The Netherlands

e-mail: bergsma@fsw.eur.nl
} 
typically equate the good life with a life that meets moral tenets. One could argue that it would be better to judge whether the advice would inspire people to behave more kindly towards their fellow human beings, since this may have been what the advisor wanted to accomplish.

Yet, the moral view on happiness is usually accompanied by the implicit promise that living up to moral standards will make life more enjoyable and a lot of readers seem to pick up this suggestion. Hence it still makes sense to investigate whether this advice is likely to produce this result.

\section{Comparable conditions?}

A second reason to question the fairness of our procedure is that some papers have judged old advice applied to modern circumstances. We use data from modern happiness research as a standard for Epicurus, Schopenhauer and the classic Chinese philosophers, but they gave their advice in social circumstances that were quite, or very, different from those of modern day industrialized nations. We investigated the utility of the advice for modern readers. We cannot do the same for contemporaries of these philosophers, because data is lacking for people from those times. Despite this, a lot of readers see eternal wisdom in these advisory texts and in this context it is not wrong to test their applicability to modern conditions.

\section{Data limitations}

A third reason to question our results has to do with the limitations of the data. There is a large body of correlational data about happiness, but still our understanding of the individual dynamics of happiness and human thriving is limited (e.g. Seligman, \& Csikszentmihaly, 2000; Diener, 2000). and hence we cannot check the appropriateness of all the advice.

\section{Use of the advice}

Another limitation is that we discuss the effects for average people who would take the advice to heart. In real life the interaction between the wise and their followers is more dynamic. Consider the following thought experiments.

In his book There is a spiritual solution to every problem self-help guru Wayne Dyer (2003) tells his readers how he had to endure a heart attack. For $24 \mathrm{~h}$ he was anxious and tense, but then he decided to become happy again. He joked with his nurses and cardiologist and told his wife he loved her during treatment. The great pessimist Arthur Schopenhauer (1995/ 1890) defended a radically different view on life. According to him happiness is not possible and the highest aim is to free yourself from pain and to make life bearable. Schalkx, \& Bergsma (2007) show that it is likely that a reader who follows Schopenhauer's advice will lose happiness.

Now for argument's sake, let us assume that Dyer is an enlightened adviser and offers a key to remaining happy in all bad circumstances. If so, we are still unable to 
conclude that everybody would profit by reading Dyers book and would be harmed by Schopenhauer's book. Readers will not always take the advice literally, but will also compare themselves socially with the authors. Just as a comparison with Einstein might make you feel humble and might make you perform less well intellectually, a comparison with Dyer might make you feel inadequate by contrast (Stapel, $\&$ Winkielman, 1998). The chances are that a minor row with your partner will upset you more than the heart attack upset Dyer; and you may decide that the marvelous spiritual solutions are not available for you because you lack character.

Schopenhauer's neurotic advice may give you the impression that you are better off than you thought you were and that you have reason to be satisfied with yourself. Reading his The wisdom of life and counsels and maxims allows you to make a downward social comparison with a renowned philosopher who's fame was based on his advice for a happy life! Alternatively, Schopenhauer's advice may serve as a warning that you should better control your own pessimistic disposition or otherwise you might become just like the author. Schopenhauer's bad advice may well be more happiness enhancing for some readers than good advice from Dyer.

\section{Diverse readership}

Another limitation of the evidence tests in this issue is that they ignore personality differences. Effects of advice will in part depend on the personality of the people who want to follow it. (See Bergsma, 2007, for a more elaborate discussion). There are many different ways, in which to become happy; and some personality traits will influence, which options are best for a given individual. A one-size-fits-all approach is implicated in any general review of happiness advice for average citizens. The same is true for lifestyle advice to enhance health. A lot of people that adopt healthy habits do so to prevent themselves succumbing to diseases for which they lack vulnerability (e.g. DeRidder, 2003; Austin, 2001). Yet, the happiness advice is typically presented as applicable to everybody and this claim does justify performing a test of general applicability.

\section{Agenda for further research}

This special issue presents a first attempt to check systematically the usefulness of happiness advice. It shows that this approach is feasible in principle but that it is also beset with problems. What are the promising ways to proceed further?

Our first recommendation is to take a broader view on advisory traditions. In this issue we have focused on teachings in the original works, but it would also be worthwhile to inspect how the counsel has changed over time. For example: How have Epicureanism, Confucianism, Taoism and Buddhism evolved since the original ideas were ventured? This change in recommendations may shed light on the applicability of the counsel in the context of socio-cultural changes.

Some recommendation themes can be studied in greater detail, for example specific best-selling self-help books with a spiritual or psychological background. Future research should also look at case studies different from those that were chosen for this special issue: there are many influential advisers available we had to 
ignore. There is no reason to stick to explicit happiness advice presented in the mass media. What is the implicit advice given in literature, movies or consulting-rooms of physicians and psychotherapists? And what are the effects of the lifestyles and mental attitudes that are favored by the great religions?

An important addition to the studies presented would be to focus on the interaction between the advice and the person that listens to it. It is a gross simplification to think that people listen to advice and then 'just do it'. Listeners are much more active than this. For example, it may not be that serious if one author offers a limited view on happiness, if his or her audience will also listen to other advisers. It would be very interesting to know more about the way people use the advice in daily living and how they choose to follow one lead and to ignore another.

A last theme for future research is to test the effects of the advice empirically. A start already has been made by testing bibliotherapy for psychological disorders. Bibliotherapy appears to be as effective as individual or group psychotherapy under certain conditions (Bergsma, 2007). Is this effect exclusive for a therapy program or does the same happen with growth oriented happiness advice? Empirical studies will make it possible to determine those for whom happiness advice works and for whom it does not. For example, one could ask different groups of students to read the classical Chinese philosophical texts of Confucianism, Buddhism and Taoism. Happiness research suggests that these classical texts may be expected to have different effects on the happiness of the readers of these texts. Confucianism may be expected to be happiness enhancing for those who allow themselves to be influenced by the classic texts, and classic Buddhism happiness might be expected to be happiness reducing (Guoqing and Veenhoven, 2007). If this effect does not occur, we should ask ourselves whether the state of happiness research is such that we are able to make a distinction between good and bad happiness advice. Do we have enough data and insight to reach out to the general audience?

\section{References}

Bergsma, A. (2007). Do self-help books help? Journal of Happiness Studies, this issue, DOI 10.1007/ s10902-006-9041-2.

De Ridder, D. (2003). Verre doelen, onmiddellijke frustraties; zelf-regulatieprocessen in gezondheidsgedrag. Utrecht: Universiteit Utrecht.

Diener, E. (2000). Subjective Well-Being; The science of happiness and a proposal for a national index. American Psychologist, 55, 1.

Dyer, W. (2003). There is a spiritual solution to very problem. New York: Harper Collins.

Guoqing, Z., \& Veenhoven, R. (2007). Advice for a Good Life in Classic Chinese Philosophy; Is it helpful for a Happy Life in Modern Society? Journal of Happiness Studies, this issue, DOI 10.1007/s10902-006-9037-y.

Schalkx, P., \& Bergsma, A. (2007). Arthur's advice; Comparing Arthur Schopenhauers advice on happiness with contemporary research. Journal of Happiness Studies, this issue, DOI 10.1007/ s10902-006-9039-9.

Schopenhauer, A. (1995/1890). The wisdom of life and Counsels and maxims. (translated by T. Bailey Saunders) New York: Prometheus Books.

Seligman, M. E. P., \& Csikszentmihaly, M. (2000). Positive psychology; An introduction. American Psychologist, 55, 1.

Stapel, D. A., \& Winkielman, P. (1998). Assimilation and contrast as a function of context-target similarity, distinctness, and dimensional relevance. Personality \& Social Psychology Bulletin, 24, 634-647. 